\title{
MJN INVESTIGATION ON THE PENSION PATTERNS OF THE AGED IN LUOYANG
}

\author{
Huang Yang \\ Student Counsellor, Luoyang Institute of Science and Technology, P R of China \\ Corresponding Author's Email: maryhuang72@163.com
}

\begin{abstract}
Objective: This study aims to investigate on the endowment patterns of the elderly in Luoyang; and meanwhile, discussing the differences between foreign nations and China in terms of endowment modes. Methods: Total 100 older people from urban area of Luoyang were investigated between January 2021 and February 2021. A questionnaire-based survey was conducted to elderly participants. We also conducted the structured interview for some residents as well as community staff. Results: The need for spiritual support for the older generation is strongest. Therefore, they tend to choose the pattern of Home Care and Home-based Community Care during their later lives. Conclusion: The government should give priority to pension policies and regulations in order to help more senior residents to have a pleasant later life.
\end{abstract}

Keywords: Nursing Homes; Older Residents; Home Care; Home-based Community Care

\section{INTRODUCTION}

Since 1991, China has entered an aging population society (Mao et al., 2020). According to international norms, $10 \%$ of the population is aged 60 and above or $7 \%$ is at least 65 years old (Tian \& Ma, 2002). As a result of the seriousness in the phenomenon of aging population in China, currently, the elderly pension problem is increasing concerned of the government and society. In recent years, with the increase in the number of elderly and disability of the elderly, family structure minimization and core, as well as family care capacity weakening, traditional home care provided by adult children is facing quite a few problems in ensuring the life quality of the elderly (Wong \& Tang, 2006).

\section{The Present Situation of Social Endowment Development in Luoyang City}

Taking Luoyang for an example, which is author's hometown and also a third line city with over 6 million population. Specifically, it has about 1.03 million people over the age of 60 (Huang, 2017). At present, there are three types of pension in Luoyang, namely Home Care, Home-based Community Care and Nursing Home. In order to know more about the choice of endowment patterns of the aged in Luoyang, the author designed and distributed a questionnaire survey.

\section{METHODOLOGY}

\section{Study Design and Participants}

This survey was conducted between January 2021 and February 2021 in the city center of Luoyang city. Luoyang is in the west of the capital city of Henan Province, named Zhengzhou. Luoyang is an ancient tourist city. The author chose Xiyuan Park to distribute questionnaires. This is because it is a good place where quite a few senior citizens do exercise all years around. About 100 subjects were chosen, who were knowledgeable and aware, with no communication barrier, no serious vision problem or hearing barrier.

\section{Survey Method}

The method of questionnaire survey was adopted for this study. The participants are required to complete this questionnaire by himself if he is able to. If not, we will provide assistants by helping the elderly to fill in the questionnaire in order to ensure the authenticity and validity of the samples. About 100 questionnaires were issued and 100 feedback questionnaires were received back. The recovery rate of questionnaires was $100.00 \%$, eliminating the missing and unqualified questionnaires, and valid questionnaires occupied $98.0 \%$ out of 100 . 


\section{RESULTS}

Table 1: Contents of the Questionnaire

\begin{tabular}{|c|c|c|c|c|c|c|}
\hline Gender & Male & Female & & & & \\
\hline $\mathrm{N}=94$ (number) & 53 & 47 & & & & \\
\hline \multirow{2}{*}{$\begin{array}{l}\text { Age } \\
\text { Number }\end{array}$} & $60-69$ & $70-79$ & 80 and over 80 & & & \\
\hline & 48 & 39 & 13 & & & \\
\hline \multirow[t]{2}{*}{ Education Level } & Primary & $\begin{array}{l}\text { Middle } \\
\text { School }\end{array}$ & High School & $\begin{array}{c}\text { Bachelor and } \\
\text { Over }\end{array}$ & & \\
\hline & 5 & 18 & 65 & 12 & & \\
\hline \multirow[t]{2}{*}{ Self-Care Ability } & $\begin{array}{c}\text { full self- } \\
\text { care }\end{array}$ & $\begin{array}{c}\text { Partial self- } \\
\text { care }\end{array}$ & $\begin{array}{c}\text { Totally } \\
\text { Incapable }\end{array}$ & & & \\
\hline & 64 & 36 & 0 & & & \\
\hline \multirow[t]{2}{*}{ Living Conditions } & Alone & With Spouse & With Children & $\begin{array}{c}\text { With } \\
\text { Grandchildren }\end{array}$ & $\begin{array}{l}\text { With Spouse } \\
\text { and Children }\end{array}$ & $\begin{array}{c}\text { Other } \\
\text { Percentage }\end{array}$ \\
\hline & 12 & 39 & 26 & 8 & 5 & 10 \\
\hline \multirow[t]{2}{*}{$\begin{array}{l}\text { Current Income Per } \\
\text { Month }\end{array}$} & $\begin{array}{l}\text { Less } \\
\text { Than } \\
3000 \\
\text { Yuan } \\
\end{array}$ & $\begin{array}{c}\text { Between } \\
3000 \text { and } \\
60000\end{array}$ & More Than 6000 & & & \\
\hline & 51 & 47 & 2 & & & \\
\hline \multirow[t]{2}{*}{ Relationship with Family } & Harmony & $\begin{array}{c}\text { General } \\
\text { Harmony }\end{array}$ & Not Harmonious & & & \\
\hline & 39 & 48 & 13 & & & \\
\hline \multirow[t]{2}{*}{ Psychological Situation } & $\begin{array}{l}\text { Regular } \\
\text { Anxiety }\end{array}$ & $\begin{array}{l}\text { Occasional } \\
\text { Anxiety }\end{array}$ & Never Anxious & & & \\
\hline & 21 & 73 & 6 & & & \\
\hline
\end{tabular}

Among the 100 elderly subjects, males occupy 53\% while females account for $47 \%$. In terms of education level, $65 \%$ of old adults received high school education and only $12 \%$ of old people acquired a bachelor's degree. This indicates that the educational level of these old pensioners is concentrated in high school education. From the way of living, those who live alone and those who live with their spouse occupy $12 \%, 39 \%$, respectively. This illustrates that more than half of the elderly live in an empty nest. From the point of economic income, the monthly income was below 3000-yuan, $3000 \sim 6000$ yuan, over 6000 yuan account for $51 \%, 47 \%$ and $2 \%$, respectively. This shows that most of the elderly economic income is relatively low.

Among the elderly surveyed, those who have a harmonious or ordinary relationship with their family account for $39 \%$ and $48 \%$, respectively. With respect to the source of income, the choice of retirement fund is the main way for the elderly to support their later lives, which occupies $54.0 \%$. Moreover, provided by children and endowment insurance are also an important source of income for the elderly, accounting for $18 \%, 20 \%$, respectively.

The survey also finds that the need for spiritual support for the older generation is strongest. It is generally acknowledged that with the gradual development of economy and society, the expansion of old-age insurance and the improvement of children's economic support ability, the quality of life of the elderly has been basically guaranteed. However, the happiness of life is not only the satisfaction of material life, but also the enjoyment of spirit. According to this survey, senior citizens are more eager for emotional care and spiritual enrichment.

Home care is the first choice. According to the survey, $48 \%$ of the elderly would like to choose the form of Home Care, $28 \%$ old pensioners are more likely to choose Home-based Community Care, while only $7 \%$ of old adults prefer to select the form of Institutional Pension. This is closely related to the reality that old people economic income is generally not high. Consequently, they are neither willing nor able to go to nursing homes with higher fees to spend their later lives.

Individual Interviews Regarding Choice of Endowment Patterns

\section{Subject: Uncle Liu, Day Care Center}

Uncle Liu, 70-year-old, grey hair, wearing a dark 
blue cotton dress and being interested in playing chess. He said currently, the most suitable endowment pattern for him would be day care pattern. Uncle Liu was a manager of the state-owned enterprise before retirement. Five years ago, he suffered from a car accident. Since then, his daily routine depends on walking sticks. His wife died of heart attacks three years ago and he felt pain and was depressed at that time. He and his wife had been married for more than 40 years and their relationship was very close. To his surprise, his only son leaves home after graduation and finds a well-paid job in a metropolitan city. Through mutual consultation, Uncle Liu's son arranged for him to go to a nearby Day Care Center where old people acquire day care during the daytime and they can enjoy family life during the nighttime. At the beginning, Uncle Liu seemed not to adapt to this new environment. However, staff from Day Care Center provided him with daytime care, entertainment, spiritual comfort, nutrition and meals, medical rehabilitation and so on. He gradually makes many friends during daily activities three months later.

\section{Subject: Aunt Wang, Home-based Community Care}

Aunt Wang, 67-year-old, outgoing personality, preferring to do square dancing. She claimed that the most favorite way of endowment for her would be Homebased Community Care. Aunt Wang was a worker and retired nearly 20 years. She currently lives alone, and her two daughters are married, and they go to see her regularly. She was diagnosed with breast cancer two years ago. After timely treatment, at present her disease is under control. Referring to old-age care, Aunt Wang does not want to leave home or cause trouble for her daughter. After much inquiry and personal inspection, she believes Home-based Community Care can meet all her needs.

\section{Subject: Community Manager}

Mr. Li, a middle aged and handsome man with humorous character. He believes that nowadays Homebased Community Care is a feasible way of supporting the aged in China. He explains that Home-based Community Care includes two types, one is door to door service provided by community staff with professional training, another is day care services provided by Day Care Center in communities. He adds that in terms of the form, community home endowment keeps the pattern of traditional family endowment, but it reflects the change from traditional mode to modern pattern in connotation. Mr. Li said regarding living mode, the elderly could have multiple choices, such as living separately or alone, going with their children regularly as well as living together with them. On endowment fund, old people have the independent economic source such as pension, insufficient parts that could be subsidized by their children, relatives or friends. In the way of daily life care, it is seen that the community and children and other relatives can jointly provide old-age care services.

\section{DISCUSSION}

Generally speaking, in comparison to the western societies, China's current situation is old before rich (Mao et al., 2020). In other words, the pension system and facilities in western countries are relatively mature. It is shown that they have modern medical equipments, professional staff, quiet and comfortable nursing facilities, as well as the wholesome system as a guarantee. However, up to now, China's pension policies, nursing institutions and relevant services are far from meeting the actual needs of the elderly.

There are three types of endowment pattern in Australia, namely pension in retirement apartment, community supported home care and hospital-style pension. To ensure the legitimate rights and interests of the elderly, Australian government sets up the Australian Aged Care Quality Agency. It is precisely because the nursing bodies and community services are in right place that the basic needs of the elderly in Australia can be met. Nursing home in Australia have a beautiful environment, professional nurses, responsible care workers, strict management system and smile faces of the aged and so on (Chen et al., 2014). The context of policy-making has significantly changed over the past years with increasing awareness among senior officials of the importance of evidence-based policy-making (Meng et al., 2004).

At the same time, the government also should seriously take the development of community management services into account. The use of long-term care services varies of the disabled elderly imposes a substantial burden on families. Studies revealed that informal care involves huge opportunity costs to the caregivers. Chinese policy makers need to promote community care and long-term care insurance to ease the load of families of disabled elderly, and consideration should be given to the rural elderly ( $\mathrm{Li}$ et al., 2013). Many older people remain under home in China. As a result, there was an interaction and joint effect between the degree of disability and the living arrangements. Therefore, policymakers should pay close attention to care for those living alone, childless, and disabled elders to meet their care needs, especially at home care. In addition, the social construction of facilities for elders in rural areas should be strengthened (Zhang, Zeng, \& Fang, 2017). 
Findings indicate that self-support ability of the elderly together with pension benefits are more operative in enhancing the life fulfilment of retired urban elderly in China. It is recommended that government institute policies to promote personal finance initiatives by the elderly while improving the pension scheme and reducing pension inequality (Abruquah, Yin, \& Ding, 2019). However, it is a different story in Chinese context. There are some widespread problems in China's nursing homes, such as financial difficulties, lack of support of the feasible policies and public support, outdated equipment's and insufficient staff with poor training. According to the survey, nowadays, increasing more individuals in Luoyang are more likely to choose Homebased Community Care to spend their later lives. Therefore, the government should give strongly support the development of Home-based Community Care from the policy.

\section{CONCLUSION}

All in all, the government should consider to draw lessons from foreign positive experiences, such as setting up subjects of community service to train more new staff, cultivating the professional talents who are engaged in the theoretical research of community service, and carrying out basic service training. This will improve the level of socialized management service of the aged. In addition, it would be a better the way to enhance the construction of laws and regulations of social welfare institutions, and to encourage more social organizations to join the team of community old-age service. Only in these ways, could more senior citizens easily find suitable pension patterns for themselves and happily enjoy the rest of their lives.

\section{Conflict of Interests}

The author declares that he has no conflict of interest.

\section{ACKNOWLEDGMENT}

The author is thankful to the institutional authority for completion of the work.

\section{REFERENCES}

Abruquah, L.A., Yin, X., \& Ding, Y. (2019). Old age support in urban China: The role of pension schemes, self-Support ability and intergenerational assistance. International Journal of Environmental Research and Public Health, 16(11), 1918.

Chen, Z., Song, Y., Yu, J., \& Wang, J., (2014). Differential development strategies of aged care support and continuity services in China, Japan, and Australia. Journal of Clinical Gerontology and Geriatrics, 5(2), 36-41.

Huang, Y. (2017). The Living Status in China's Disabled Elderly--Taking an Example of Luoyang. Nursing \& Care Open Access Journal, 3(5), 304-305.

Li, M., Zhang, Y., Zhang, Z., Zhang, Y., Zhou, L., \& Chen, K. (2013). Rural-urban differences in the long-term care of the disabled elderly in China. PloS One, 8(11), e79955.

Mao, G., Lu, F., Fan, X., \& Wu, D. (2020). China's ageing population: The present situation and prospects. Population Change and Impacts in Asia and the Pacific, 269-287.

Meng, Q., Shi, G., Yang, H., González-Block, M.A., \& Blas, E. (2004). Health Policy and Systems Research in China (No. TDR/GEN/SEB/04.1). World Health Organization.

Tian, Z. H., \& Ma, X. (2002). Analysis of the influence of aging problem on social security service system for the aged and its solutions. Northwest Population, 2, 17-18.

Wong, L., \& Tang, J. (2006). Non State Care Homes for Older People as Third Sector Organizations in China's Transitional Welfare Economy. Journal of Social Policy, 35(2), 229-246.

Zhang, L., Zeng, Y., \& Fang, Y. (2017). The effect of health status and living arrangements on long term care models among older Chinese: A cross-sectional study. PloS One, 12(9), e0182219. 